\title{
Cell transplantation comes of age
}

\author{
Richard D. Weisel, MD
}

Ren-Ke Li, MD

Donald A. G. Mickle, MD

Terrence M. Yau, MD

From the Division of Cardiovascular Surgery, The Toronto Hospital, Toronto, Ontario, Canada.

Richard D. Weisel, Ren-Ke Li, and Donald A. G. Mickle are consultants to and receive research funding from the Genzyme Corporation, Cambridge, Mass.

R. D. Weisel was a Career Investigator of the Heart and Stroke Foundation of Canada and $\mathrm{R} . \mathrm{K} . \mathrm{Li}$ is a Research Scholar of the Heart and Stroke Foundation of Ontario.

Received for publication Feb 7, 2001; accepted for publication Feb 9, 2001.

Address for reprints: Richard D. Weisel, MD, FRCS, Division of Cardiovascular Surgery, The Toronto Hospital, 200 Elizabeth St, EN 14-215, Toronto M5G 2C4, Ontario, Canada (E-mail: Richard.Weisel@uhn.on.ca).

J Thorac Cardiovasc Surg 2003;125:S53-4 Originally published in J Thorac Cardiovasc Surg 2001;121:835-6.

Copyright () 2003 by The American Association for Thoracic Surgery

$0022-5223 / 2003 \$ 30.00+0$

doi: $10.1067 / \mathrm{mtc} .2003 .223$

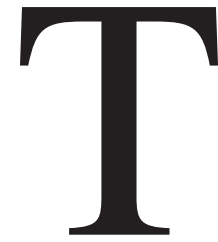

he results of the first clinical experience with cell transplantation were reported to the American Heart Association in November 2000 by Menasche and associates ${ }^{1}$ of Paris. A 72 -year-old man who had a transmural myocardial infarction with an ejection fraction of $21 \%$ received skeletal myoblasts implanted into the infarct region at the time of coronary bypass surgery. Five months later, he had recovered from the operation, and perfusion and function of the infarct region had improved, perhaps related to the cell transplantation. This initial case report provides hope that the damage from an extensive myocardial infarction may be reversed. Coronary bypass surgery is frequently inadequate to restore function in patients who have few viable surviving myocytes in the infarct region. Cell transplantation offers the promise of restoring function in these unfortunate patients. ${ }^{2-4}$ However, the era of cell transplantation has only begun. Major questions remain. What type of cell is appropriate for autotransplantation? When should these cells be delivered and by what route? What is the efficacy of cell transplantation relative to other medical and surgical treatments? What outcome measures can be used to compare alternative treatments in blinded randomized trials?

A number of research groups have implanted heart cells, ${ }^{2}$ skeletal muscle cells, ${ }^{3}$ smooth muscle cells, ${ }^{4}$ and bone marrow stem cells ${ }^{5}$ into injured myocardium. The implanted cells engrafted within the injured region and improved regional perfusion, wall thickening, and wall motion, as well as global function. The animal studies and the initial clinical experience suggest that cell transplantation has great potential, but the mechanism of benefit remains incompletely characterized. Histologic studies suggest that the engrafted cells induce angiogenesis. The cells orient against the cardiac stress and prevent thinning and dilatation of the injured region. Careful sonometric studies performed at Duke University suggest that engrafted skeletal myoblasts altered the elasticity of the scarred region. ${ }^{3}$ The altered elastic properties of the engrafted region and the angiogenesis that is induced may have prevented cardiac remodeling, avoiding cardiac thinning and dilatation and congestive heart failure.

The benefits of cell transplantation have been shown without demonstrating that the implanted cells beat synchronously with the native heart. Heart cells implanted into normal myocardium have been shown to communicate with native cardiomyocytes by intercalated disks, ${ }^{6}$ but heart cells implanted into an infarct region have not been shown to communicate with the recipient cardiomyocytes. ${ }^{2}$ Skeletal myocytes implanted into an infarct region appear to adopt a cardiac cell-like morphology, but electrochemical connections permitting synchronous contractility have not been demonstrated. ${ }^{7}$ Smooth muscle cells proliferate and hypertrophy in response to the stress of cardiac contractions, but do not beat. ${ }^{4}$ Mesenchymal stem cells derived from adult bone marrow can differentiate toward a cardiac phenotype and have been induced to beat synchronously in vitro. ${ }^{8}$ These cells communicate with the normal cardiomyocytes by intercalated disks. However, mesenchymal cells implanted in an infarct region did not beat synchronously with the heart. ${ }^{9}$ Future studies should establish whether the implanted cells assume a cardiac morphology, whether they communicate with the normal myocardium, and whether they beat synchronously with the heart. Sonomicrometry permits an excellent assessment of 
regional dimensions and thickening, but sonomicrometry cannot differentiate implanted from hibernating native cells in the infarct region. We used $99^{\mathrm{m}}$ technetium-Sestambi single-photon emission tomography to evaluate perfusion and wall motion in the infarct zone. Echocardiography offers the hope of detecting synchronous contraction of the transplanted cells.

In this issue of the Journal, Rajnoch and colleagues ${ }^{10}$ present an interesting study of skeletal myoblast implantation after cardiac injury. Their study suggests that satellite cell implantation improved both regional and global function. In most animal models used to evaluate cell transplantation, cardiac injury is induced either by coronary ligation or by cryoinjury resulting in cardiomyocyte loss and remodeling of the infarct region. Remodeling has been uniformly associated with thinning and dilatation of the infarct region and deterioration of global function. In the sheep model used in this study, the myocardium was injured by intramyocardial injection of a snake cardiotoxin. Unfortunately, the sequence of events after the injection of the toxin was not well documented in the control group. In some control animals, the injured region thinned and the heart dilated. In the transplant group, the heart did not dilate and global function did not deteriorate. However, a blinded comparison between control and transplant animals is necessary to accurately conclude that cell transplantation improved global or regional function.

Regional ventricular function is extremely difficult to assess. The authors of this study used color kinesis echocardiography, which tracks regional movement. Unfortunately, cardiac motion may alter the echo region interrogated, and changes in preload, afterload, and ventricular shape and size can influence the measurements. These variables may have differed between control and treatment animals. Therefore, the authors have not convincingly demonstrated a difference in regional contractility, although their results are suggestive.
In summary, cell transplantation offers the promise of restoring regional function for patients who have had an extensive myocardial infarction. The recent report from Paris demonstrates the clinical feasibility of this new surgical technique. Future studies will need to establish the relative efficacy of this approach. Carefully conducted clinical trials using sensitive and specific end points may help us to determine the relative value of cell transplantation.

\section{References}

1. Menasche P, Hagege AA, Scorsin M, Pouzet B, Desnos M, Duboc D, et al. Myoblast transplantation for heart failure. Lancet. 2001;357:27980.

2. Li R-K, Weisel RD, Mickle DAG, Jia Z-Q, Kim E-J, Sakai T, et al. Autologous porcine heart cell transplantation improved heart function after a myocardial infarction. J Thorac Cardiovasc Surg. 2000;119: 62-8.

3. Taylor DA, Atkins BZ, Hungspreugs P, Jones TR, Reedy MC, Hutcheson KA, et al. Regenerating functional myocardium: improved performance after skeletal myoblast transplantation. Nat Med. 1998; 4:929-33.

4. Li R-K, Jia Z-Q, Weisel RD, Merante F, Mickle DAG. Smooth muscle cell transplantation into myocardial scar tissue improves heart function. J Mol Cell Cardiol. 1999;31:513-22.

5. Wang J-S, Shum-Tim D, Galipeau J, Chedrawy E, Eliopoulos N, Chiu RC. Marrow stromal cells for cellular cardiomyoplasty: feasibility and potential clinical advantages. Ann Thorac Surg. 2000;120:999-1006.

6. Soonpaa MH, Koh GY, Klug MG, Field LJ. Formation of nascent intercalated disks between grafted fetal cardiomyocytes and host myocardium. Science. 1994;264:98-101.

7. Scorsin M, Hagege A, Vilquin JT, Fiszman M, Marotte F, Samuel JL, et al. Comparison of the effects of fetal cardiomyocyte and skeletal myoblast transplantation on postinfarction left ventricular function. J Thorac Cardiovasc Surg. 2000;119:1169-75.

8. Makino S, Fukuda K, Miyoshi S, Konishi F, Kodama H, Pan J, et al. Cardiomyocytes can be generated from marrow stromal cells in vitro. J Clin Invest. 1999;103:697-705.

9. Tomita S, Li R-K, Weisel RD, Mickle DAG, Kim EJ, Sakai T, et al. Autologous transplantation of bone marrow cells improves damaged heart function. Circulation. 1999;100(Suppl):II-247-56.

10. Rajnoch C, Chachques J-C, Berrebi A, Bruneval P, Benoit M-O, Carpentier A. Cellular therapy reverses myocardial dysfunction. J Thorac Cardiovasc Surg. 2001;121:871-8. 